\title{
GPR30 expression and function in breast cancer cells are induced through a cis-acting element targeted by ETS factors
}

\author{
DAVID SEGURA-BAUTISTA ${ }^{1,2}$, ALEIDA OLIVARES ${ }^{1}$, PATRICIA CASAS-GONZÁLEZ ${ }^{1}$, \\ EDMUNDO BONILLA ${ }^{3}$, ZAYIL SALAZAR ${ }^{2}$ and MARCO ALLÁN PÉREZ-SOLIS ${ }^{1}$

\begin{abstract}
${ }^{1}$ Medical Research Unit in Reproductive Medicine, UMAE Hospital de Gineco Obstetricia no. 4 'Luis Castelazo-Ayala', Instituto Mexicano del Seguro Social, México City 01090; ${ }^{2}$ Biological and Health Sciences PhD Program and

${ }^{3}$ Departament of Health Science, Universidad Autónoma Metropolitana, Iztapalapa, México City 09340, México
\end{abstract}

Received August 9, 2019; Accepted January 16, 2020

DOI: $10.3892 /$ or.2020.7540

\begin{abstract}
The capacity that $\mathrm{G}$ protein-coupled receptor 30 (GPR30) has demonstrated for triggering estrogen-dependent signaling pathways has attracted the interest of breast cancer researchers; however, the reported expression profiles and functions of GPR30 in breast cancer are inconsistent. The main purpose of the present investigation was to identify transcriptional mechanisms underlying the expression of GPR30 that allow a better understanding of its role in breast cancer progression. In the cell lines used as different polarity models in the present study, it was determined immunologically that GPR30 is expressed in normal mammary gland cells and that this expression decreased considerably during breast cancer development, where cell identity is lost. However, it was also determined that, in spite of low GPR30 expression levels in breast cancer cells with little differentiation, this membrane estrogen receptor (ER) is able to increase cell viability and suppress migration in cells that have acquired metastatic capacity. In addition, through transient expression assays in breast cancer cells, it was revealed that a transcriptional mechanism dependent on protein kinase $\mathrm{A}$ and susceptible to retinoic acid in ER-positive cells induces GPR30 expression through a cis-regulatory element for E26 transformation-specific transcription factors, located between -631 and $-625 \mathrm{bp}$ from the GPR30 translation start codon. Overall, these results suggested that in vitro transcriptional regulation of GPR30 expression in breast cancer cells may serve a relevant role in the conservation of an epithelial phenotype, and also may be important to avoid the transition to metastasis.
\end{abstract}

Correspondence to: Dr Marco Allán Pérez-Solis, Medical Research Unit in Reproductive Medicine, UMAE Hospital de Gineco Obstetricia no. 4 'Luis Castelazo-Ayala', Instituto Mexicano del Seguro Social, 289 Av. Río Magdalena, Level 6, Tizapan San Angel, C.P., México City 01090, México

E-mail: marco_perezsolis@yahoo.es

Key words: G protein-coupled receptor 30 promoter, cell viability, metastasis, transcription, breast cancer

\section{Introduction}

With the current advances in determining the mechanisms underlying estrogen-dependent cell proliferation in breast cancer, it has been possible to treat patients with in situ (or even invasive) ductal carcinoma, which are estrogen receptor (ER) $\alpha$ positive, through hormone therapy with antagonist molecules, such as tamoxifen or fulvestrant (1). Although these treatments are partially responsible for an $\sim 40 \%$ decrease in the mortality rate over the last three decades (2), one-third of patients with breast cancer are not positive for hormone nuclear receptors and, therefore, do not respond favorably to such treatments. These treatments may be detrimental for certain intrinsic molecular subtypes (3). In the last 20 years, signal transduction through $\mathrm{G}$ protein-coupled receptor 30 (GPR30) has been considered a mechanism involved in the resistance to endocrine therapy, owing to its ability to trigger signaling pathways induced by antiestrogens (4). Additionally, it has been reported that GPR30 serves a regulatory role in several cellular processes, such as migration (5), proliferation (6) and cell survival (7) in breast cancer.

Although GPR30 was initially classified as an orphan receptor, subsequent biochemical studies demonstrated that this membrane receptor is strongly stimulated by estrogens, as well as by other compounds, including insecticides (i.e., DDT), phytoestrogens (i.e., genistein), xenoestrogens (i.e., bisphenol A) and antagonistic modulators of ER $\alpha$ and ER $\beta$ (i.e., fulvestrant and tamoxifen) $(8,9)$. In addition, selective binding compounds for GPR30, such as the agonists G1 [1-(4-[6-bromobenzo-(1,3)-dioxol-5-yl]-3a,4,5,9btetrahydro-3H-cyclopenta-[c]-quinolin-8-yl)-ethanone] and G36 [4-(6-bromo-benzo-[1,3]-dioxol-5-yl)-8isopropyl-3a,4,5,9 b-tetrahydro-3H-cyclopenta-(c)-quinoline], and the antagonist G15 [4-(6-bromo-benzo-[1,3]-dioxol-5-yl)-3a,4,5,9b-tetrahydro-3H-cyclopenta-(c)-quinoline], have been synthesized to monitor the specific biological activity of GPR30 (10-12).

Previous studies on GPR30 function have reported the involvement of this receptor in the induction of the epidermal growth factor receptor/ERK signaling pathway that promotes tamoxifen resistance (13), as well as in the transactivation of genes linked to proliferation and migration in breast cancer, such as connective tissue growth factor and $\mathrm{N}$-acylsphingosine 
amidohydrolase $1(14,15)$. There is also evidence that GPR30 expression in breast cancer can be regulated by a positive feedback loop with hypoxia-inducible factor 1 (HIF-1) (16). Recently, it was also reported that the activity of both proteins, GPR30 and HIF-1, is linked to a complex crosstalk process with the Notch1 signaling pathway, which in turn induces epithelial-mesenchymal transition (EMT) (17). However, the data reported thus far from GPR30 expression and function studies during the course of breast cancer is contradictory; for example, GPR30 expression has been reported to be downregulated during breast cancer development, and variously reported to function as a suppressor or inducer of proliferation or migration (14,18-26). Considering the importance of the expression profile of GPR30 for the integral understanding of its role in the progress of breast cancer, the present study aimed to determine the transcriptional mechanisms that regulate GPR30 expression in cellular models of different breast cancer subtypes (metastatic and non-metastatic).

\section{Materials and methods}

Cell cultures. The non-metastatic MCF-7 [HTB-22; American Type Culture Collection (ATCC)] and metastatic MDA-MB-231 (HTB-26; ATCC) breast cancer cell lines, as well as the normal breast cell line MCF-10A (CRL-10317; ATCC), were cultured in DMEM (Gibco; Thermo Fisher Scientific, Inc.) supplemented with 10\% FBS (Gibco; Thermo Fisher Scientific, Inc.), Leibovitz's L-15 medium (Gibco; Thermo Fisher Scientific, Inc.) supplemented with 10\% FBS and Mammary Epithelial Cells Growth Medium (Lonza Walkersville, Inc.) supplemented with cholerae toxin (Sigma-Aldrich; Merck KGaA), respectively. All cultures were incubated at $37^{\circ} \mathrm{C}$ in a $5 \% \mathrm{CO}_{2}$ atmosphere. All cell lines were tested for mycoplasma and cellular authentication by commercial PCR Mycoplasma Detection Set (Takara Bio, Inc.), according with to manufacturer's instructions, and capillary electrophoresis in a 3500 Genetic Analyzer (Applied Biosystems; Thermo Fisher Scientific, Inc.), respectively.

Western blotting. For GPR30 immunoblotting, total protein was isolated from $1.5 \times 10^{6}$ cells of MCF-10A, MCF-7, MDA-MB-231 by lysis with RIPA buffer (1 M Tris/HCl pH 7.4; 6.5 M EDTA pH 8.0; $5 \mathrm{M} \mathrm{NaCl}$; 0.4\% deoxycholate; $0.8 \%$ IGEPAL-CA-630), PMSF and Complete Mini protease inhibitor cocktail tablets (Roche Diagnostics). For the ETS translocation variant (ETV)1, ETV4 and ETV5 immunoblots, nuclear extracts were obtained from MCF-10A, MCF-7 and MDA-MB-231 cell lines, following the protocol described by Schreiber et al (27). The total and nuclear protein extracts $(80 \mu \mathrm{g})$ were separated by $10 \%$ SDS-PAGE and transferred to PVDF membranes (EMD Millipore). Subsequently, the membranes were incubated overnight with the following primary antibodies in TBS-Tween 20 (TBST; $50 \mathrm{mM}$ Tris; $140 \mathrm{mM} \mathrm{NaCl} ; 0.1 \%$ Tween-20) with 4\% BSA: Anti-GPR30 (1:625; cat. no. ab39742; Abcam), anti-E26 transformation-specific (ETS) translocation variant (ETV4; 1:100; cat. no. sc-113; Santa Cruz Biotechnology, Inc.), anti-ETV5 (1:250; cat. no. sc-22807; Santa Cruz Biotechnology, Inc.) and anti-ETV1 (1:250; cat. no. ab81086; Abcam). As loading control, GAPDH expression was detected with anti-GAPDH
(1:10,000; cat. no. MAB374; Merck KGaA) for total extracts. Commercial nuclear extracts of MCF-7 (cat. no. sc-2149; Santa Cruz Biotechnology, Inc.) and K-562 (cat. no. sc-2130; Santa Cruz Biotechnology, Inc.) were used as positive controls (40 $\mu \mathrm{g}$ ) for ETV5 and ETV4, respectively. In the case of ETV1 and GPR30, $80 \mu \mathrm{g}$ of total mouse brain and OVCAR3 nuclear extracts (courtesy of Ms. Isis Santos Paniagua) were used as positive controls, respectively. The membranes were washed 3 times (15 min each) with TBST buffer and subsequently incubated with the following horseradish peroxidase-conjugated secondary antibodies: Goat anti-rabbit immunoglobulin G (IgG; 1:12,000; cat. no. 111-035-003, Jackson ImmunoResearch Laboratories, Inc.) and goat anti-mouse IgG (1:10,000; cat. no. 115-035-003; Jackson ImmunoResearch Laboratories, Inc.). Immune complexes were visualized by enhanced chemiluminescence with SuperSignal West Pico Chemiluminescent Substrate (Pierce; Thermo Fisher Scientific, Inc.), according to the manufacturer's instructions in a C-DiGit Blot Scanner (LI-COR Biosciences) during an exposure of $12 \mathrm{~min}$ and analyzed by Image Studio v2.1 software(LI-COR Biosciences).

Cell viability assay. MCF-7 and MDA-MB-231 cells were seeded into 96 -well culture plates at a density of $7.5 \times 10^{3}$ cells/well. The adhered cells were subjected to a starvation period of $16 \mathrm{~h}$ and stimulated afterwards with either $10 \mu \mathrm{M}$ or $20 \mu \mathrm{M}$ G15 (Azano Biotech) or $10 \mu \mathrm{M}$ G1 (Azano Biotech) (Fig. S1) or $10^{-6} \mathrm{M}$ retinoic acid (RA; Sigma-Aldrich; Merck $\mathrm{KGaA}$ ) or vehicle (DMSO) incorporated into the corresponding growth medium. Cells were subsequently fixed at 0 , 24, 48 and $72 \mathrm{~h}$ with $1.1 \%$ formaldehyde for $15 \mathrm{~min}$, washed with water three times and left to dry at room temperature. The cells were stained with crystal violet for $20 \mathrm{~min}$, washed three times with water and allowed to dry at room temperature. Finally, $10 \%$ acetic acid was added for $20 \mathrm{~min}$. The absorbance of each well was determined at $590 \mathrm{~nm}$ using a Synergy HT microplate reader (BioTek Instruments, Inc.).

Migration assay. A migration assay was performed on the MCF-7 (Fig. S2) and MDA-MB-231 metastatic cell lines. Cells were seeded in 6 -well culture plates with a $7.5 \times 10^{5}$ cell density and grown in Leibovitz's L-15 medium (Gibco; Thermo Fisher Scientific, Inc.) supplemented with $10 \%$ FBS, until they reached confluence. The cell monolayer was carefully wounded using a $100 \mu 1$ pipette tip and the detached cells were removed by washing with PBS. The wounded monolayer cultures were subjected to a $24 \mathrm{~h}$ starvation period and were incubated afterwards for $48 \mathrm{~h}$ in serum-free medium containing $5 \mu \mathrm{M} \mathrm{G} 1$ (Azano Biotech) or $5 \mu \mathrm{M} \mathrm{G1}+10 \mu \mathrm{M} \mathrm{G15}$ (Azano Biotech). Images of the wounds were capture at 0,24 and $48 \mathrm{~h}$ using an Axiovert 25 microscope (Carl Zeiss AG) with a CP-Achromat 10x/0.25 Ph1 objective (Carl Zeiss AG) and a PowerShot A580 digital photographic camera (Canon, Inc.) equipped with a DC150 camera adapter (Leica Microsystems GmbH). The wound areas were analyzed with the Icy bioimage analysis software v2.0.3.0 (http://icy.bioimageanalysis.org).

GPR30 5' flanking region cloning. MCF-7 and MDA-MB-231 cells seeded and grown to $75 \%$ confluence in $100 \mathrm{~mm}$ plates and genomic DNA was isolated according to the procedure described by Sambrook et al (28). A 1,987 bp DNA fragment 
from both genetic materials was amplified by PCR using the following thermocycling conditions: Initial denaturation of $94^{\circ} \mathrm{C}$ for $30 \mathrm{sec}$; followed by 30 cycles of $94^{\circ} \mathrm{C}$ for $30 \mathrm{sec}$, $50.4^{\circ} \mathrm{C}$ for $1 \mathrm{~min}$, and $68^{\circ} \mathrm{C}$ for $4 \mathrm{~min}$, followed by a final extension at $68^{\circ} \mathrm{C}$ for $7 \mathrm{~min}$. PCR was carried out with an Expand Long Template PCR system (Roche Diagnostics) and the pair of specific primers described in Table I. The amplification product was separated by $1.0 \%$ agarose gel electrophoresis, visualized by Visual Violet Gel Additive (Amresco, LLC), purified with a Gene Clean III kit (Bio 101; MP Biomedicals, LLC) and ligated with T4 DNA Ligase (Promega Corporation) into a pGEM-T vector (Promega Corporation), according to the manufacturer's instructions. The recombinant plasmid was propagated in JM109 Escherichia coli (Promega Corporation) and purified with a Wizard Plus SV Minipreps system (Promega Corporation). To obtain a reliable sequence of the cloned fragment, three different recombinant plasmids of each cell line were sequenced with a Big Dye Terminator System and an ABI PRISM 77 automatic sequencer (Applied Biosystems; Thermo Fisher Scientific, Inc.).

Sequence analysis. The nucleotide sequences obtained from the fragment of the $5^{\prime}$ flanking region of GPR30 cloned from the MCF-7 and MDA-MB-231 cell lines was analyzed using BLAST (National Center for Biotechnology Information; http://blast.ncbi.nlm.nih.gov). Both sequences were compared with each other and with the chromosome 7 sequence reported with the AC091729 accession number in the EMBL nucleotide sequence database (https:/www.ncbi.nlm.nih. gov/nuccore/18643712). In addition, the binding sites for transcription factors were scanned with the prediction program in the JASPAR website (http://jaspar.genereg.net).

Reporter gene constructs. The recombinant plasmid harboring the human GPR30 promoter from MCF-7 cells was used as template to amplify five segments of different lengths $(0.2$, $0.5,1.0,1.5$ and $2.0 \mathrm{kbp}$ ), using specific forward and reverse primers with $B g l \mathrm{II}$ and $H$ ind III restriction sites, respectively. Each amplicon was purified using a GeneClean III Kit (MP Biomedicals, LLC) and subsequently digested with BglII and HindIII restriction enzymes (Roche Diagnostics). Each digested segment was again purified and cloned into a pGL3-Enhancer firefly luciferase reporter vector (Promega Corporation), previously digested with the same restriction enzymes. The resulting constructs (pGPR2.0, pGPR1.5, pGPR1.0, pGPR0.5, and pGPR0.2) were amplified by transformation in competent JM109 E. coli cells (Promega Corporation). The putative cis-acting elements located at -628 , $-754,-892$ - and $-896 \mathrm{bp}$ from the translation start codon (TSC) were selected based on their high similarity with consensus sequences for ETS, negative glucocorticoid response element (NGRE), estrogen-related receptor $\alpha$ (ERR1), SRY-box transcription factor (SOX), and by site-directed mutagenesis in their 'core' sequence using the reporter construct pGPR1.0 as the template and the specific oligonucleotides described in Table I. Reporter constructs with loss-of-function mutations $(\mu)$ were indicated as $\operatorname{ETS} \mu, \operatorname{NGRE} \mu, \operatorname{ERR} \mu$ and $\operatorname{SOX} \mu$, and the construct with the only gain-of-function mutation was named ETSc. Three clones of each plasmid were selected to verify the fidelity of the mutagenesis procedure by incorporation of fluorescent dideoxynucleotides using the Big Dye Terminator system (Applied Biosystems; Thermo Fisher Scientific, Inc.), according to the manufacturer's instructions.

Transfections. MCF-10A, MCF-7 and MDA-MB-231 cell lines were cultured in 96-well plates with a density of $1.5 \times 10^{4}$ cells/well. The three cell lines were transiently transfected with $100 \mathrm{ng}$ of each reporter gene construct, using the FuGENE HD Transfection reagent (Roche Diagnostics) according to the manufacturer's protocol. A total of $100 \mathrm{ng}$ of pGL3 Enhancer (Promega Corporation) plasmid was transfected to determine the background luminescence, and the pRL-TK Renilla luciferase control reporter plasmid $(25 \mathrm{ng})$ was co-transfected as a normalization control. After $48 \mathrm{~h}$ of expression, luciferase activity was measured using the Dual-Luciferase Reporter assay system (Promega Corporation) in a Sirius L Single Tube Luminometer (Titertek-Berthold).

Transient expression assays with phosphorylation inhibitors. To assess the role of the main phosphorylation pathways activating the ETS factors associated with breast cancer in the regulation of the GPR30 promoter region with the functional ETS binding site, p38 kinase inhibitor SB203580, protein kinase A (PKA) inhibitor H89, and ERK inhibitor PD98059 (all from Merck KGaA) were used at a $10 \mu \mathrm{M}$ concentration each in transient expression assays. Transient transfections were performed in the three cell seeded $\left(1.5 \times 10^{4}\right.$ cells/well $)$ in 96-well plates. Each well was transfected with $100 \mathrm{ng}$ of the reporter constructs pGPR0.5 and pGPR1.0 with or without inhibitors. The empty pGL3-Enhancer vector (100 ng/well) and pRL-TK (25 ng/well) were transfected as the background and internal control, respectively. After $22 \mathrm{~h}$ of starvation, each of the three inhibitors was added to the growth medium. Luciferase activity was measured $48 \mathrm{~h}$ after the application of the inhibitors using the Dual-Luciferase Reporter assay system in a Sirius L Single Tube Luminometer, aforementioned.

Stimulation assays with RA. MCF-7 cells were cultured in 96-well plates at a density of $1.5 \times 10^{4}$ cells/well, and transfected with pGPR0.5 or pGPR1.0, aforementioned, and subsequently synchronized for $24 \mathrm{~h}$ with DMEM without phenol red (Sigma-Aldrich; Merck KGaA), supplemented with inactivated FBS (HyClone; GE Healthcare Life Sciences) and stimulated with increasing RA concentrations in DMSO $\left(0,10^{-12}, 10^{-11}, 10^{-10}, 10^{-9}, 10^{-8}, 10^{-7}\right.$ and $\left.10^{-6} \mathrm{M}\right)$ for $48 \mathrm{~h}$. Reporter gene activity was measured using the Dual-Luciferase Reporter assay system in a Sirius L Single Tube Luminometer, aforementioned.

Reverse transcription (RT)-PCR assays. MCF-7 cells were seeded at a density of $7.5 \times 10^{5}$ cells in $60 \mathrm{~mm}$ dishes with DMEM supplemented with $10 \% \mathrm{FBS}$ and incubated at $37^{\circ} \mathrm{C}$ in a $5 \% \mathrm{CO}_{2}$ humid atmosphere for $24 \mathrm{~h}$. Subsequently, the cells were washed with PBS and synchronized for $24 \mathrm{~h}$ with free-serum DMEM medium without phenol red. Later the cells were treated with RA $\left(10^{-6} \mathrm{M}\right)$ or with vehicle (DMSO) for $48 \mathrm{~h}$. At the end of the stimulation, cells were washed with cold PBS and lysed with $1 \mathrm{ml}$ of Trizol ${ }^{\circledR}$ (Invitrogen; Thermo Fisher Scientific, Inc.). The cell lysate was mixed vigorously with $0.2 \mathrm{ml}$ of chloroform (MP Biomedicals, 
Table I. Oligonucleotides used in the different applications.

\begin{tabular}{|c|c|c|}
\hline Gene & Oligonucleotide sequence $\left(5^{\prime} \rightarrow 3^{\prime}\right)$ & Length (nt) \\
\hline \multicolumn{3}{|l|}{ Genomic DNA } \\
\hline 5FGPR30-s & AAGCAATAGGTCAACAAATCTCTAG & 25 \\
\hline 5FGPR30-as & GTCTCTGCACCGTGCAGCTTTCAAGA & 26 \\
\hline \multicolumn{3}{|c|}{ Reporter construction } \\
\hline pGPR2.0 & ACGCAGATCTTGTCAACAAATCTCTAG & 27 \\
\hline pGPR1.5 & ACGCAGATCTTCTTGGGCACCTGTCCTAG & 29 \\
\hline pGPR1.0 & ACGCAGATCTTGACTCTCTCCCTGGAG & 27 \\
\hline pGPR0.5 & ACGCAGATCTTTTCCCACAGGCGACTC & 27 \\
\hline pGPR0.2 & ACGCAGATCTTAGCATCTGTTCTTCCC & 27 \\
\hline pGPR-as & ACGAAGCTTGTCTCTGCACCGTGCAGC & 27 \\
\hline \multicolumn{3}{|c|}{ Reverse transcription-PCR } \\
\hline \multirow[t]{2}{*}{ GPR30 } & F: TTCAGCAGTGCCGTGTAGA & 19 \\
\hline & R: GTGTGCAGCTCCCGAGTC & 18 \\
\hline \multirow[t]{2}{*}{ ETV5 } & F: GTTGTGCCTGAGAGACTGGAAG & 22 \\
\hline & R: CATTGGCTGGGTCATCAAGAAG & 22 \\
\hline \multirow[t]{2}{*}{ ETV4 } & F: CCCAACAAATGCCCATTTCATTGC & 24 \\
\hline & R: AACGCTCACCAGCCACCTTC & 20 \\
\hline \multirow[t]{2}{*}{ ETV1 } & F: GTACCACGACCCAGTGTATGAAC & 23 \\
\hline & R: GGATGAGCCAGGAAGCCTTC & 20 \\
\hline \multirow[t]{2}{*}{ GAPDH } & F: GCTCTCTGCTCCTCCTGTTTC & 21 \\
\hline & R: ACGACCAAATCGTTGACTC & 19 \\
\hline \multicolumn{3}{|l|}{ Mutagenesis } \\
\hline $\mathrm{ETS} \mu$-s & TACCTTCATTGCCCCCTGGGCCTGCTC & 27 \\
\hline $\mathrm{ETS} \mu$-as & GAGCAGGCCCAGGGGGCAATGAAGGTA & 27 \\
\hline $\mathrm{SOX} \mu-\mathrm{s}$ & ATTTCCCAAAACCATGACCCCTTTC & 25 \\
\hline $\mathrm{SOX} \mu$-as & GAAAGGGGTCATGGAAAAGGGAAAT & 25 \\
\hline $\mathrm{ERR} 1 \mu-\mathrm{s}$ & TCССААААСААТТТССССТТТСАСТС & 26 \\
\hline ERR $1 \mu$-as & GAGTGAAAGGGGAAATTGTTTTGGGA & 26 \\
\hline NGRE $\mu$-s & АCTCTCTCССТGTTGTTTCTTCCTAG & 26 \\
\hline NGRE $\mu$-as & CTAGGAAGAAACAACAGGGAGAGAGT & 26 \\
\hline ETSc-s & TACCTTCATTACTTCCGGTGCCTGCTC & 27 \\
\hline ETSc-as & GAGCAGGCACCGGAAGTAATGAAGGTA & 27 \\
\hline
\end{tabular}

LLC) for $30 \mathrm{sec}$ and centrifuged for $40 \mathrm{~min}$ at $14,000 \mathrm{rpm}$ and $4^{\circ} \mathrm{C}$. The aqueous phase was recovered and mixed in $1 \mathrm{ml}$ of isopropanol (Amresco, LLC) to precipitate RNA, followed by centrifugation at $14,000 \mathrm{rpm}$ and $4^{\circ} \mathrm{C}$ for $1 \mathrm{~h}$. The RNA pellet was washed with $75 \%$ ethanol and centrifuged at $14,000 \mathrm{rpm}$ and $4^{\circ} \mathrm{C}$ for $12 \mathrm{~min}$. Finally, the total RNA was resuspended in water treated with diethyl pyrocarbonate (Thermo Fisher Scientific, Inc.). cDNA was synthesized using the Phusion RT-PCR kit (Finnzymes; Thermo Fisher Scientific, Inc.), and PCR assays were performed using the cDNA as template and specific oligonucleotides (Table I) for amplification of the transcripts corresponding to GPR30, ETV1, ETV4, ETV5 and housekeeping gene GAPDH. PCR was carried out with Clone Amp HiFi PCR mix (Clontech
Laboratories, Inc.) with the following thermocycling conditions: Initial denaturation of $94^{\circ} \mathrm{C}$ for $30 \mathrm{sec}$; followed by 30 cycles of $94^{\circ} \mathrm{C}$ for $30 \mathrm{sec}, 58^{\circ} \mathrm{C}$ for $45 \mathrm{sec}$ and $73^{\circ} \mathrm{C}$ for $1 \mathrm{~min}$, followed by a final extension period of $5 \mathrm{~min}$ at $74^{\circ} \mathrm{C}$. The amplification products were resolved in a $10 \%$ polyacrylamide gel, stained with ethidium bromide $(0.5 \mu \mathrm{g} / \mathrm{ml})$ and visualized in a UV transilluminator.

Statistical analysis. The results are expressed as the mean \pm standard deviation. Comparisons between $>2$ groups were made using ANOVA followed by Tukey's post hoc test, or by Dunnett's post hoc test for comparisons between treatments and the vehicle control. Statistical analyzes were performed using the SigmaPlot 12.0 (Systat Software, Inc.) software for 
Windows. Each assay was performed in triplicate. $\mathrm{P}<0.05$ was considered to indicate a statistically significant difference.

\section{Results}

GPR30 regulates cell viability and migration of breast cancer cells. The assays carried out for the immunodetection of GPR30 revealed a $44 \mathrm{kDa}$ band corresponding to the molecular weight of this receptor (29) in the extracts of non-malignant epithelial cells (MCF-10A) and in dedifferentiated malignant cells (Fig. 1). Densitometric evaluation of the bands obtained indicated that after the control cell line (ovarian cancer cell line OVCAR3), the non-tumorigenic mammary gland cell line MCF-10A exhibited highest relative expression level of GPR30 (7.3\%), followed by the non-metastatic breast cancer cell line MCF-7 (2.4\%) and the metastatic MDA-MB-231 line (1.2\%).

The effects of the specific GPR30 antagonist, G15, on MCF-7 and MDA-MB-231 viability was evaluated at 0,24, 48 and 72 h (Fig. 2). The viability of MCF-7 cells treated with G15 was significantly reduced at $72 \mathrm{~h}$ compared with the vehicle-treated control group (Fig. 2A). MCF-7 cells that were cultured for $72 \mathrm{~h}$ in the absence of G15 increased their absorbance 4.8 -fold compared with the $0 \mathrm{~h}$ time point, whereas G15-treated cells increased their absorbance 2.8-fold with a $10 \mu \mathrm{M}$ concentration and 2.4 -fold with a $20 \mu \mathrm{M}$ concentration. These data indicated that in cell cultures treated for $72 \mathrm{~h}$ with 10 and $20 \mu \mathrm{M} \mathrm{G} 15$, cell viability decreased regarding untreated cells 40 and $49 \%$, respectively. However, although an increase in viability in the MDA-MB-231 cell cultures was also observed with and without G15 treatment, there was a significant decrease in viability in cells treated with $20 \mu \mathrm{M}$ G15 for $72 \mathrm{~h}$ compared with vehicle-treated cells at the same time point (Fig. 2B). The absorbance obtained in untreated-cells after $72 \mathrm{~h}$ of culture was 2.6 -fold greater compared with cells at $0 \mathrm{~h}$, whereas the increase in absorbance in cells treated with 10 and $20 \mu \mathrm{M}$ G15 was 2.3 and 1.7-fold compared with the respective $0 \mathrm{~h}$ time point. These results indicated that MDA-MB-231 cell viability decreased $31 \%$ when cells were treated with $20 \mu \mathrm{M}$ G15 compared with control cells at $72 \mathrm{~h}$.

In the cell viability assays, untreated MCF-7 cell viability was increased 4.8 -fold at $72 \mathrm{~h}$ compared with the $0 \mathrm{~h}$ time point, whereas the viability of cells treated with the GPR 30 agonist (10 $\mu \mathrm{M} \mathrm{G1}$ ) increased only 2.6 -fold over the same time period (Fig. S1A). In the case of MDA-MB-231 cells, viability increased 1.9-fold after $72 \mathrm{~h}$ without treatment, whereas the G1-treated cells increased only 1.35 -fold after the same time elapsed (Fig. S1B). These data demonstrated that the viability of MCF-7 and MDA-MB-231 cells decreased significantly by 74 and $64 \%$, respectively, after $72 \mathrm{~h}$ of treatment with G1, compared with the respective control at the same time point.

The role of GPR30 in cell migration was examined by wound-healing assays with the metastatic MDA-MB-231 cell line (Fig. 2C and D), since the MCF-7 cell line showed no significant changes in its migration (Fig. S2). In untreated MDA-MB-231 cells, the wound area was reduced by $41 \%$ after $24 \mathrm{~h}$ and $56 \%$ after $48 \mathrm{~h}$. Conversely, in G1-treated cells the wound area reduced only by $13 \%$ at $24 \mathrm{~h}$ and $22 \%$ at $48 \mathrm{~h}$. To confirm that the suppressive effect of G1 on migration was through GPR30, the effect of its antagonist, G15, on migration impaired by G1 was also assayed. For this, a G15 concentration
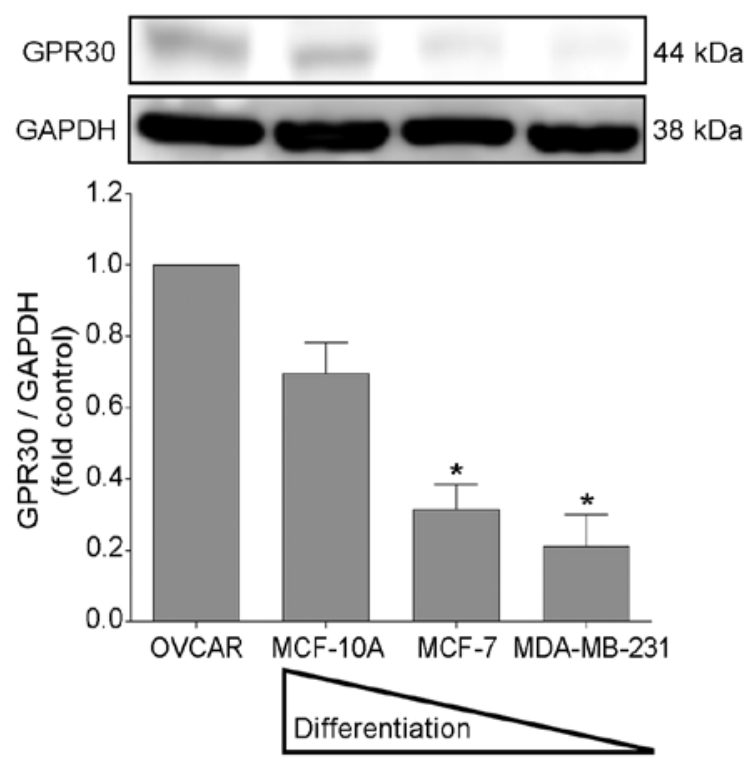

Figure 1. Expression of GPR30 protein in mammary gland cell lines. Representative immunoblot of GPR30 protein expression levels in the non-tumorigenic mammary epithelial cell line MCF-10A and the breast cancer cell lines MCF-7 and MDA-MB-231. The ovarian cancer cell line OVCAR3 was used as positive control and GAPDH was used as loading control and for normalization. Data are present as the mean \pm SEM from three independent experiments. ${ }^{*} \mathrm{P}<0.05$ vs. OVCAR3. GPR30, G protein-coupled receptor 30 .

twice as high as the minimum G1 concentration that was required to observe an effect on migration was used, since the affinity of the antagonist for the receptor is three times lower compared with that of G1 (10). The cells treated simultaneously with both G1 and G15, diminish the wound area $23 \%$ at $24 \mathrm{~h}$ and $33 \%$ at $48 \mathrm{~h}$. This means that G1-treated cells lost $39 \%$ of its migratory capacity with respect to untreated cells, while cells treated with both agonist and antagonist recovered $20 \%$ of its migratory capacity regarding cells treated only G1.

Structural analysis of the 5' flanking region of the GPR30 encoding gene. Through structural and predictive analysis of the 1,987 bp sequence cloned from the 5 flanking region of the gene encoding the GPR30 receptor, it was possible to characterize the GPR30 promoter fragment in three regions. A proximal region ranging from -1 to $-1,009 \mathrm{bp}$ from TSC with a heterogeneous sequence, and two distal regions ranging from $-1,010$ to $-1,512 \mathrm{bp}$ and $-1,513$ to $-1,987 \mathrm{bp}$ from the TSC, which have a high GC content (70\%) and a high AT content (72\%), respectively (Fig. 3). The sequence alignment of the GPR30 promoter cloned from both MCF-7 and MDA-MB-231, with the chromosome 7 sequence did not reveal any mismatch (data not shown). In addition, 14 putative cis-regulatory elements with a similarity greater than $98 \%$ in relation to consensus sequences for forkhead box P1 (FOXP1), ERR1, NGRE, brain-specific homeobox (BSX) and member of the ETS, SOX and hypoxia-inducible factors (HIF) families, were found by JASPAR program. Given its high nucleotide heterogeneity, the distribution of these possible sites of transcriptional regulation are concentrated in the proximal region, whereas owing to the low nucleotide heterogeneity of distal regions, it was only possible to find three sites in one of them (Fig. 3). 


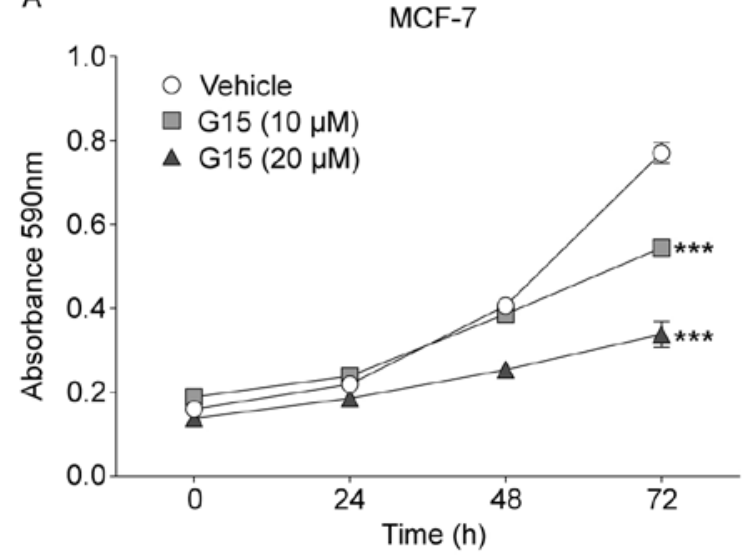

C
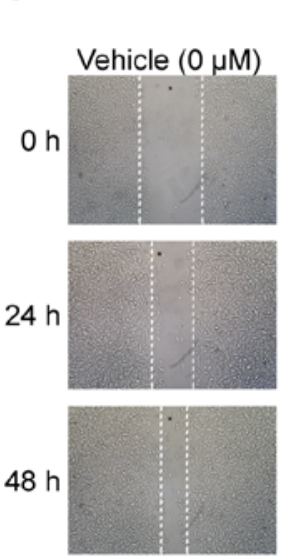

MDA-MB-231
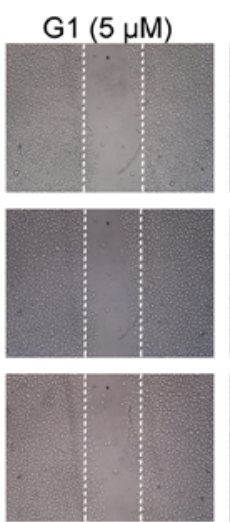

$\mathrm{G} 1(5 \mu \mathrm{M}) /$ $\mathrm{G} 15(10 \mu \mathrm{M})$
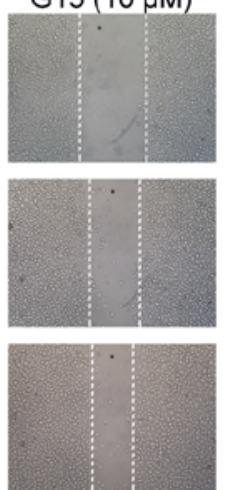

B

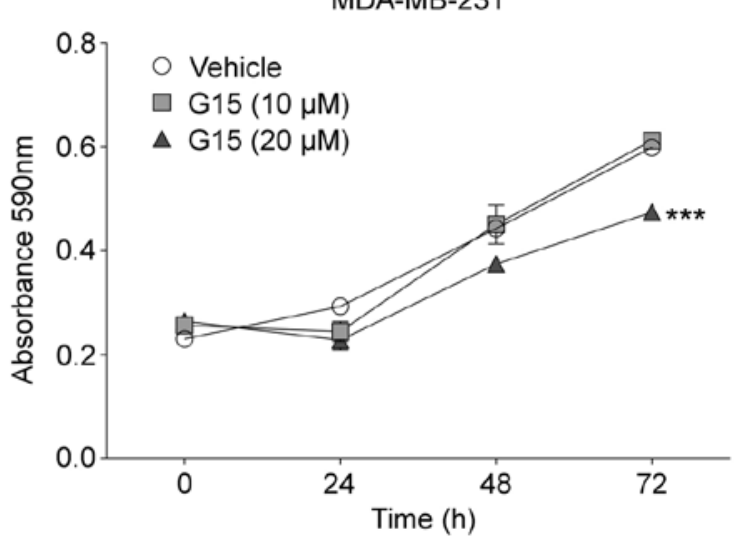

D

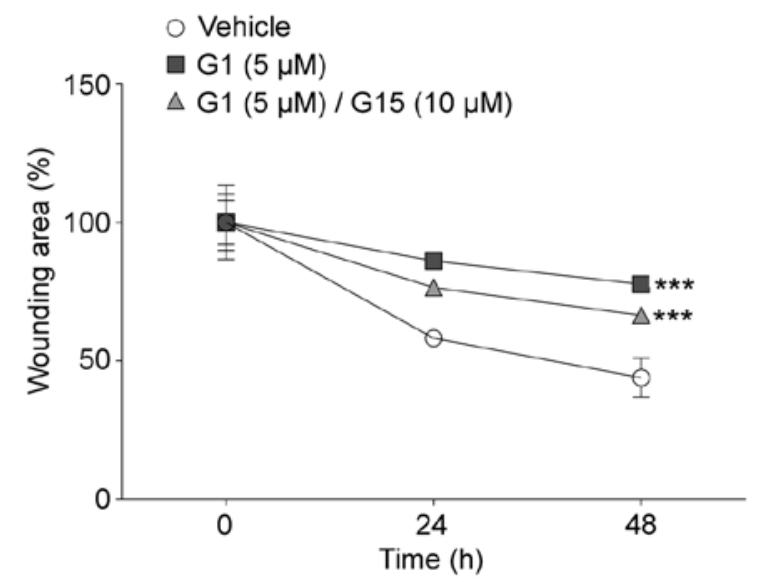

Figure 2. Effects of GPR 30 on viability and migration of breast cancer cells. Effect of G15 on the cell viability of (A) MCF-7 and (B) MDA-MB-231. ${ }^{* * *} \mathrm{P}<0.001$ vs. Vehicle at $72 \mathrm{~h}$. (C and D) Effect of GPR30 activation by G1 and the G1/G15 competition on the migration of the metastatic cell line MDA-MB-231. The migration data was measured in terms of wound width, obtained at 0,24 and $48 \mathrm{~h}$ from seven quadrants per well, considering initial wound width as $100 \%$. ${ }^{* * *} \mathrm{P}<0.001$ vs. Vehicle at $48 \mathrm{~h}$. Data are presented as the mean $\pm \mathrm{SD}$ from three independent experiments performed at least in triplicate. G1, a GPR30 agonist; G15, a GPR30 antagonist; GPR30, G protein-coupled receptor 30.

Transcriptional regulation pattern of the GPR30 promoter in breast cancer. The transient expression of the five reporter constructs governed by different length versions of the GPR30 promoter truncated at the 5 ' end (Fig. 3), revealed that even without the background activity generated by the empty vector, the transcriptional regulation pattern of the promoter turned out to be very similar in all three mammary gland cell lines. All reporter constructs transfected in the three cell lines, except pGPR1.0 in MCF-10A, produced a similar change pattern in luciferase activity. The maximum activity of GPR30 promoter was find in pGPR0.5 being this 1.6-fold higher in MCF-10A compared with in MCF-7, and approximately 8.8-fold higher compared with MDA-MB-231 (Fig. 4). Using the luciferase activity induced solely by the initial $200 \mathrm{bp}$ (pGPR0.2) of the GPR30 promoter in each cell line as the basal promoter activity, it was demonstrated that in MCF-10A cells the activity of pGPR0.5 significantly increased $93 \%$, whereas activity with pGPR 2.0 significantly decreased by $22 \%$ of basal activity of promoter. In the case of MCF-7, luciferase activity with pGPR1.5 and pGPR0.5 significantly increased 80 and $29 \%$ of basal activity, respectively. Conversely, the reporter activity of pGPR2.0 and pGPR1.0 in the same cell line, significantly decreased 44 and $50 \%$ of basal activity, respectively. Similarly, luciferase activity in MDA-MB-231 also significantly increase 98 and $71 \%$ of basal activity with pGPR1.5 and pGPR0.5, respectively. Although the activity of the reporter gene with pGPR2.0 and pGPR1.0 in MDA-MB-231 had a similar pattern of change as was observed in MCF-7, such changes were not significant (Fig. 4). Altogether, the changes observed in the three cell lines, suggest that the GPR30 promoter fragments ranging from 2.0 to $1.5 \mathrm{kbp}$ and 1.0 to $0.5 \mathrm{kbp}$ could contain transcription suppressing elements, while fragments ranging from 1.5 to $1.0 \mathrm{kbp}$ and 0.5 to $0.2 \mathrm{kbp}$ could host transcription activating elements.

A cis-regulatory element that resembles the polyomavirus enhancer activator 3 homolog (PEA3) subfamily consensus sequence, activates the GPR30 promoter. Bearing in mind the role of the sequence between $-1,009$ to -511 bp contained in the construct pGPR1.0 in the suppression of the transcription, functional analysis of the putative cis-regulatory elements for negative regulation factors located in this region was conducted. This was done by the transient expression of the $\operatorname{ETS} \mu, \operatorname{NGRE} \mu, \operatorname{ERR} \mu$ and $\mathrm{SOX} \mu$ reporter 


\begin{tabular}{|c|c|c|}
\hline-1987 & $\begin{array}{c}\text { sox } \\
\text { AGCAATAGGTCAACAAATCTCTAGTCTGGTTTTGCAGCACTTCAaaacaatAACCCCTGGCC }\end{array}$ & -1924 \\
\hline-1923 & CGGCGCGGTGGATCACACCTGTAATCCCAGCACCGTGGGAGGCCAAGGCGGGCAGATCACTAC & -1861 \\
\hline-1860 & AGGTCAGAAGTTCGATACAAGCCTGGGCAACATGGTAAAACCCCATCTCTACTAAAAATATAA & -1798 \\
\hline-1797 & AACATTAGCCAGGCGTGGTGGTGCACACCTATAATCCCAGATACTCAGGAGGCTGAGGCAGGA & -1735 \\
\hline-1734 & GAACCACTCTAACCCGGGAGGCGGCAGTTGCAGTGAGCCGAGATTGTGCCACTGCACTCCAAC & -1672 \\
\hline-1671 & $\begin{array}{l}\text { CTGGGTGACCAAAAAAAAAAAACATTCAAAACAATAACTCCTAATGATTTCAAAAGGTAAAAT } \\
\text { ETS FOXP1 }\end{array}$ & -1609 \\
\hline-1608 & GAAAATTCCCaaaggaAAaacaACTCAAACCCATTTTGAAGTGTTAGTTTACTCCAGGGCACC & $-154 \epsilon$ \\
\hline-1545 & AGCACCATCTGGGCCAGGTAATTCTCTGCTGGGCTTGGGCACCTGTCCTAGGCACTGTAGGGA & -1483 \\
\hline-1482 & GCTGAGCGGCAGCCCTGGCCCCACCAGCACCCCCCTGTGACTGCCCCCGCATCCCCAGAGACT & $-142 \mathrm{a}$ \\
\hline-1419 & GCCAGTGTCTGCAGGCTGAGACCCCCGTGGCCCGCTGCATAGAGAACTTCCAGGAGCACAGTG & -1357 \\
\hline 1356 & ACACGGGGCAGGTGACGGGACCCTCCCCACTGGCGGCAGAGCCGGGGTGACACGGGGCAGGTG & -1294 \\
\hline-1293 & ACAGGACCTCCCCACTCGCAGCAGGGCCAGGGTGACACGGGGTGGGTGATGGGACCCTCCCCA & -1231 \\
\hline-1230 & CTGGCGGCAGAGCCGGGGTGACACAGGGCAGGTGATGGGACCCTACCCACTGGCGGCAGAGCC & $-116 \mathrm{a}$ \\
\hline-1167 & GGGGTGACACGGGGCGGGTGACGGGACCTCTCCACTGGCGGCAGAGCCAGGGTGACACGGGGT & 105 \\
\hline & $\begin{array}{l}\text { GGGTGACGGGACCCTCCCCACTGGCGGCAGAGCCCGGGCACCGCCGTGGGCGGACAGCCCACT } \\
\text { DR1 }\end{array}$ & \\
\hline-10 & $\begin{array}{l}\text { TCTCCСTCTCTGCAGAGGATAAGCTCGGGAGGGACTCTCTCCCTGGAGTTTCttcctaGGTTA } \\
\text { FOXP1 }\end{array}$ & \\
\hline-97 & $\begin{array}{c}\text { CAAACAGCATTGCAAAaacaTATTAGGTTTTACAATAATTTGTTAAAACATGAAATAAAAACG } \\
\text { SOX5 ERR1 }\end{array}$ & \\
\hline-91 & $\begin{array}{r}\text { TACATATTATTTCCCAAaacaatgaccCCTTTCACTCTATATTACGAAAATAAGTTTATTTTT } \\
\text { HIF }\end{array}$ & \\
\hline-85 & $\begin{array}{l}\text { GGTACCTAGAACACAGAACTAGCATGAGGAAACCGCTGAACTTCTGTTTTATCGTAAGagaaG } \\
\text { NGRE }\end{array}$ & -7 \\
\hline-789 & $\begin{array}{l}\text { ATTCTGCTCTGATGTCCAGCTTTCTGGACCCACtctctcTCTCTCAGAAACACTGGCTTTCCC } \\
\text { ETS }\end{array}$ & -7 \\
\hline-721 & $\begin{array}{c}\text { ttcctATCTTACTTCTCCATCAGCTGCTGAAATGCATTTTCCCCTCTCCTCACAAATGCCGTT } \\
\text { ETS }\end{array}$ & -664 \\
\hline-663 & GTCCTGGGGCGGCCGTGCCCATACCTTCATTGcttcetgGGCCTGCTCTGTGGCTATAAAGGG & -601 \\
\hline-600 & $\begin{array}{l}\text { AAAAACACCCCTGCCTGTGGGAGTGACTCACGTCCAGCCTCCAGCTGCAGCTGAGCAGCCGTG } \\
\text { HIF }\end{array}$ & -5 \\
\hline-537 & GGACCTgcaggAAAGAAGGCCATGTACTTCCCACAGGCGACTCTTCCACCTCAGCTCAACCAC & -475 \\
\hline 474 & AGCCACCTCCCGAGCTCATAAAGCTGAGGTTCTGGCCCTCCCCAGTGCTCCTGACACACCCAG & -412 \\
\hline 411 & АСTСTACAGACACCCGGCCAGGGGAGCCAGGCCTTGTCCCAAAGCTGGGGCCACTCGATGAGA & -349 \\
\hline-348 & $\begin{array}{l}\text { СтTCATCCTCTCCTGTTGCTTCTCCAGGTACCCAGAGAGTGAGCAGCTCCACGCGGGACTGTG } \\
\text { HIF }\end{array}$ & -286 \\
\hline-285 & $\begin{array}{r}\text { CACGGTGGCCGACACCCgcaggGACGCCCGCCGGACGAGCACGCGGAGGGCCCTCGCCTCCAC } \\
\mathbf{B S X}\end{array}$ & -223 \\
\hline-222 & GGATGCACCATGCCGGTGTGAGGAGCATCTGTTCTTCCCACTCTCTgcagttaACAAACCCAA & -160 \\
\hline 10 & CCAAACCACCACAGGTGCTCCTCCTGGGGAGtttcctGTCTGACAAATGCCAGGCTCACTTC & -97 \\
\hline-96 & AAGGAGAATCACGCTTCTTTCTAAAGATGGATTCACCATTTAAAACAGAGCTCTGGGAGCCTT & - \\
\hline & GGCAAATCTTGAAAC & \\
\hline
\end{tabular}

Figure 3. Nucleotide sequence of the cloned 5' flanking region of the GPR30 gene. Fragment of 1987 bp upstream of the translation start codon of GPR30 gene cloned from MCF-7 and MDA-MB-231. The putative cis-regulatory elements predicted by JASPAR are indicated by bold, lowercase letters. The sequence corresponding to the oligonucleotides that were synthesized to build the different reporter constructs are indicated in shaded letters. The arrows indicate the beginning of the different regions in which GPR30 was divided. BSX, brain-specific homeobox; DR1, distal region 1; DR2, distal region 2; ERR1, estrogen-related receptor $\alpha$; ETS, E26 transformation-specific; FOXP1, forkhead box P1; GPR30, G protein-coupled receptor 30; HIF, hypoxia-inducible factor; NGRE, negative glucocorticoid response element; PR, proximal region; SOX, SRY box transcription factor.

constructs. None of the mutations exhibited increased luciferase activity, as expected; however, the $\mathrm{ETS} \mu$ mutation significantly decreased the reporter gene activity by $24 \%$ in MCF-10A, 65.8\% in MCF-7 and 46\% in MDA-MB-231 compared with the wild-type construct pGPR1.0 (Fig. 5A). Although with the site-directed mutations in the ERR $\mu$, NGRE $\mu$ and $\operatorname{SOX} \mu$ constructs also is observed a decrease in the reporter gene activity in any of transfected cell lines, these changes were not statistically significant. The functionality of a putative ETS cis-regulatory element was confirmed by comparing the activity of pGPR 1.0 and the construct containing an ETS factor consensus elements (ETSc) in the MDA-MB-231 cell line (Fig. 5B). As expected, the luciferase activity obtained with ETSc was 1.27 -fold greater compared with the pGPR 1.0 construct containing the wild-type GPR 30 promoter. 
A

\begin{tabular}{|c|c|c|c|c|c|}
\hline & & & & & $C_{1}$ \\
\hline A & B & c & D & $\mathrm{E}$ & $\mathrm{F}$ \\
\hline pGPR2.0 & pGPR1.5 & pGPR1.0 & pGPR0.5 & pGPR0.2 & pGL3-Enhancer \\
\hline
\end{tabular}

B

$\operatorname{RLU}\left(\mathrm{x} 10^{4}\right) \quad \operatorname{RLU}\left(\mathrm{x} 10^{4}\right) \quad \operatorname{RLU}\left(\mathrm{x} 10^{4}\right)$

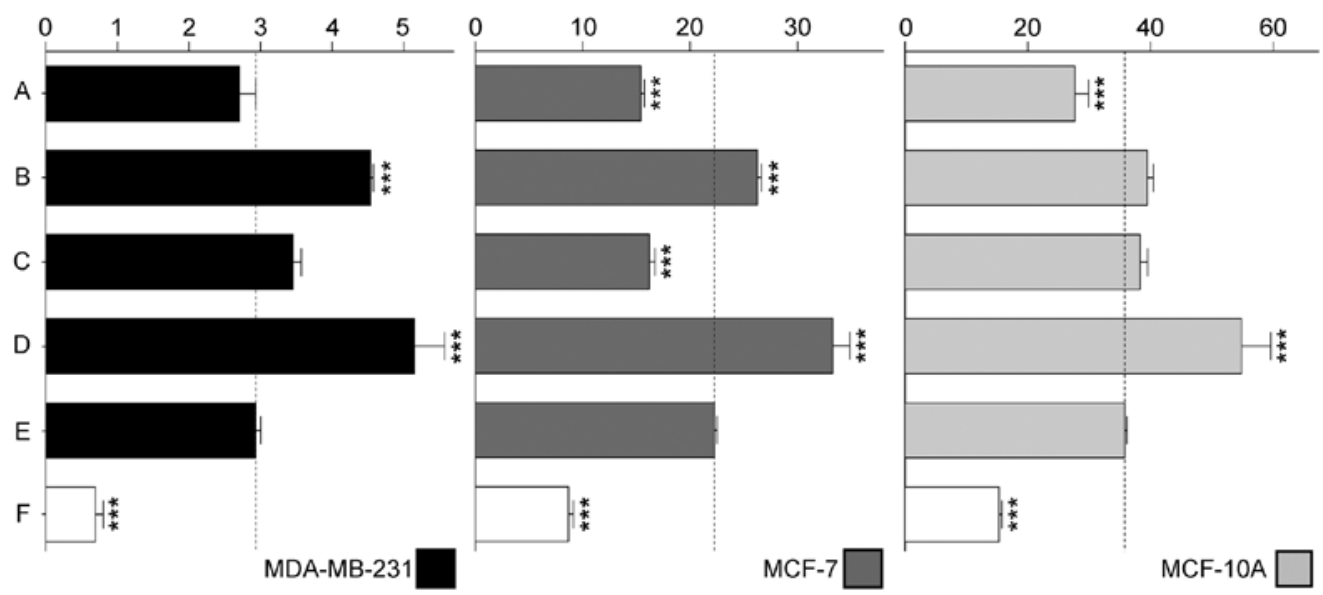

Figure 4. Transcriptional regulation of the GPR30 promoter cloned in mammary gland cell lines with different differentiation grade. (A) Schematic representation of the firefly pGL3-Enhancer luciferase reporter plasmid, driven by different 5'-truncated segments of the GPR30 promoter: pGPR2.0, pGPR1.5, pGPR1.0, pGPR0.5 and pGPR0.2. (B) Cells were co-transfected with the different constructs of the GPR30 promoter or pGL3-Enhancer (white bar) and the plasmid pRL-TK (Renilla luciferase) in the MCF-10A, MCF-7 and MDA-MB-231 cell lines, for assay promoter activity (RLU). Data are presented as the mean \pm SD of three independent experiments performed in triplicate; ${ }^{* * *} \mathrm{P}<0.001$ vs. basal levels (pGPR0.2). GPR30, G protein-coupled receptor 30 ; RLU, relative luminescence units; TSC, translation start codon.

In addition, to gather additional evidence regarding the participation of any of the factors of the ETS family in the positive regulation of the GPR 30 promoter observed with the ETS element studied, the common phosphorylation pathways of such factors were inhibited to verify if GPR30 promoter activity decreases. For this, transient expression assays performed with pGPR1.0 (with ETS sites) and pGPR0.5 (without an ETS site) on MDA-MB-231 cells, treated with SB203580 (p38 inhibitor), H89 (PKA inhibitor) and PD98059 (ERK1/2 inhibitor) demonstrated statistically significant changes only with the $1.0 \mathrm{kbp}$ GPR30 promoter in presence of H89 and PD98059, reducing its activity to 0.59 and 0.79 -fold, respectively (Fig. 5C). Similar assays using the pGPR0.5 construct had no significant effect on the activity of the reporter gene, since the ETS factors of the PEA3 subfamily require the phosphorylation of PKA and ERK to perform their transcriptional activity (30-32), and given that the functional ETS element identified is located in the region affected by these inhibitors (pGPR1.0); the results obtained from assays with protein kinases inhibitors point to ETV1, ETV4 and ETV5 as the factors with the greatest possibility of interacting with this element.

The activity of the factors of the PEA3 subfamily have been closely related to the development of breast cancer (33-37), but the expression of each of them may be committed to specific phenotypes. To confirm which of these factors may be active in the cellular models in the present study, and possibly involved in the activation of the GPR30 promoter through the inducing ETS element, their expressions were verified qualitatively by immunoblotting assays (38). ETV5 has been previously reported as a factor expressed by MCF-7 (39). Therefore, the immunoblotting with anti-ETV5 was carried out using a commercial MCF-7 nuclear extract as positive control. This assay confirmed the expression of a $72 \mathrm{kDa}$ protein that correspond to the molecular weight of ETV5 factor (40) in the nuclear extracts of all mammary gland cell lines used in the previous experiments and in the nuclear extract of positive control as expected. Conversely, a $66 \mathrm{kDa}$ protein corresponding to the molecular weight of ETV4 was detected with anti-ETV4 only in the positive control extract (K-562) (40). In addition, a $62 \mathrm{kDa}$ protein corresponding to the molecular weight of ETV1 (40) was also detected with anti-ETV1 in the nuclear extracts of the MCF-7 cell line and the positive control (mouse brain) (Fig. 5D). These results suggested that ETV5 and ETV1 may be able to transactivate GPR30 expression through the ETS element found as functional in pGPR0.1

$R A$ suppresses the activity of the GPR30 promoter and its ETS site located at $-630 \mathrm{bp}$. Since RA suppresses proliferation in ER-positive breast cancer $(41,42)$ and regulates the expression of several factors of the ETS family (43), dose-response assays with this metabolite were carried out on the MCF-7 cell line transfected with pGPR0.5 (without ETS site) and pGPR1.0 (with ETS site). In the case of the pGPR0.5 construct, the reporter gene activity exhibited a statistically significant suppression of $28.1 \%$ only when it was exposed to a final concentration of $10^{-6} \mathrm{M}$. By contrast, with the pGPR1.0 construction containing the inducer element for ETS factors, the activity of the promoter decreased significantly from $10^{-11} \mathrm{M}$ concentration and continued significantly decreasing up to $60 \%$ with the highest concentration (Fig. 6A). In addition, the transient expression assays in RA-treated and untreated MCF-7 cells with the transfected pGPR1.0, ETSc or ETS $\mu$ constructs, exhibited a statistically significant decrease of $\sim 50 \%$ in luciferase activity promoted by pGPR1.0 and ETSc, 
A

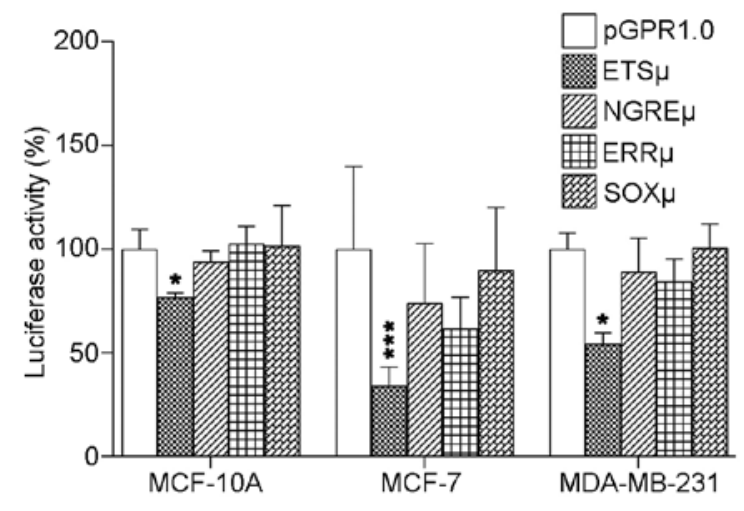

C

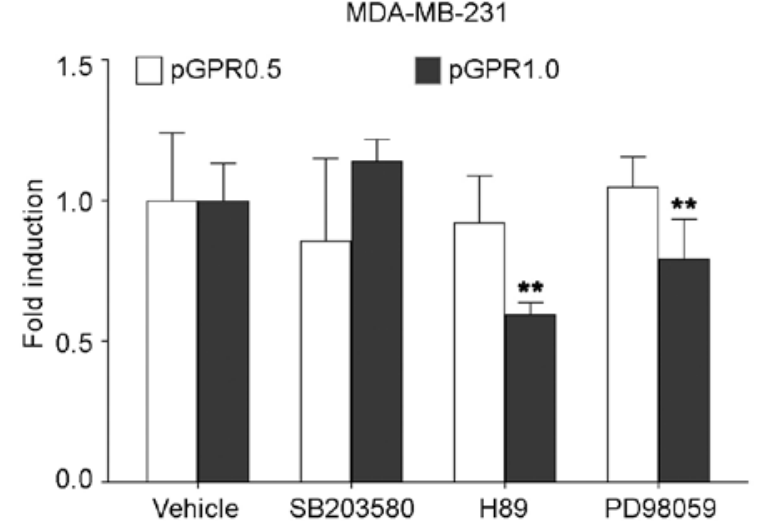

B

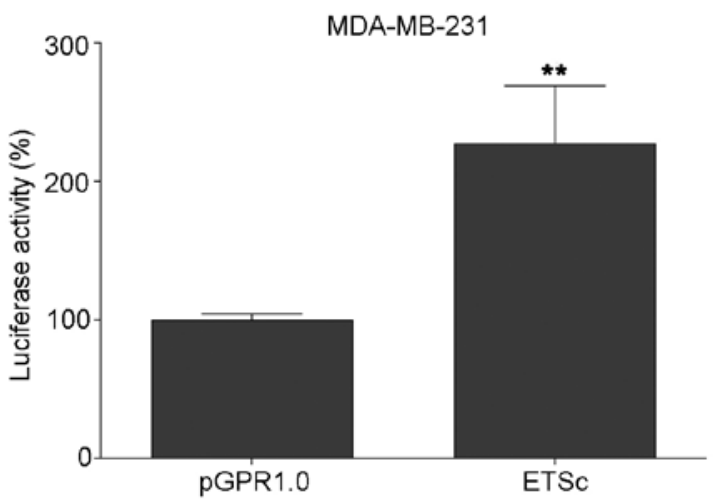

D

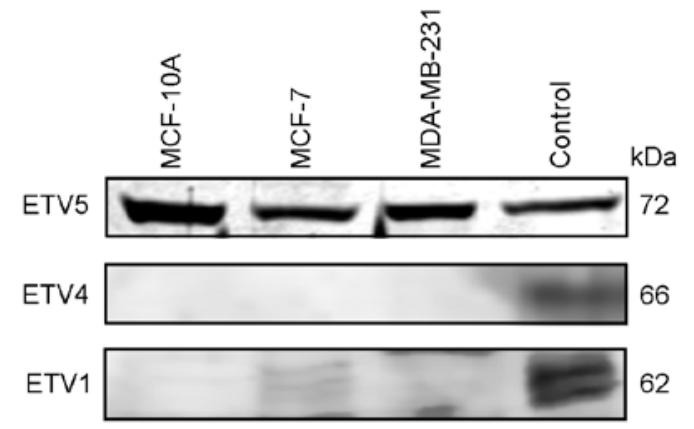

Figure 5. PEA3 subfamily is involved in GPR30 transactivation in breast cancer cells. Reporter gene activity (Firefly luciferase) induced by the pGPR1.0 construct and its (A) loss-of-function mutant versions ETS $\mu$, NGRE $\mu$, ERR $\mu$, and SOX $\mu$ in MCF-10A, MCF-7 and MDA-MB-231 cells and (B) gain of function mutant, ETSc, in MDA-MB-231 cells. ${ }^{*} \mathrm{P}<0.05,{ }^{* *} \mathrm{P}<0.01$ and ${ }^{* * *} \mathrm{P}<0.001$ vs. pGPR0.1. (C) Effects of the inhibitors of p38 (SB203580), PKA (H89) and ERK1/2 (PD98059) on reporter gene activity of the GPR30 promotor constructs pGPR0.5 without the functional ETS site (white) and pGPR1.0 containing ETS site (black) in MDA-MB-231 cells. ${ }^{*} \mathrm{P}<0.05,{ }^{* *} \mathrm{P}<0.01$ and ${ }^{* * *} \mathrm{P}<0.001$ vs. Vehicle. (D) Immunoblots of ETV5, ETV4 and ETV1 performed with nuclear extracts of MCF-10A, MCF-7, MDA-MB-231 and positive controls as was described in the Materials and methods. Data are presented as the mean \pm SD of three independent experiments in triplicate. ETS, E26 transformation-specific; NGRE, negative glucocorticoid response element; ERR1, estrogen-related receptor $\alpha$; SOX, SRY-box transcription factor; PKA, protein kinase A; PEA3, polyomavirus enhancer activator 3 homolog; GPR30, G protein-coupled receptor 30.

when the cells are treated with RA, while with $\mathrm{ETS} \mu$ no effect was observed (Fig. 6B).

The RT-PCR assays of GPR30 and its possible transcriptional regulators, performed with total RNA isolated from MCF-7 cells exhibited a notable decrease in amplicon production of GPR30, ETV5, ETV4 and ETV1 transcripts in RA-treated cells compared with the vehicle-treated cells (Fig. 6C). Similarly, viability assays using RA-treated MCF-7 cells showed no significant changes in absorbance during different culture times, whereas the absorbance of vehicle-treated MCF-7 cells increased $21 \%$ at $48 \mathrm{~h}$ and $67 \%$ at $72 \mathrm{~h}$ of cultivation. No significant differences in viability were identified in RA-treated cells at any time point compared with the respective $0 \mathrm{~h}$ control, which indicated a complete depletion of viability in MCF-7 cells associated with RA (Fig. 6D).

\section{Discussion}

A few years after the identification of GPR30 as an orphan receptor in 1996 (44), the expression and function of this membrane receptor in breast cancer was intensively studied.
However, although it has been reported that the expression of GPR30 in the mammary gland is null (45) or restricted to myoepithelial cells (46), Scaling et al (47) have provided evidence that suggests the involvement of GPR30 in upregulation of the in vitro proliferation of breast tissue epithelial cells. Conversely, data reported by other research groups regarding the role of GPR30 in breast cancer not allowed to infer its therapeutic importance (6,48-50). The lack of a well-defined expression pattern of GPR30 in the course of breast cancer hinders the correct interpretation of evidence concerning the role that this receptor may serve in the development of this malignancy (7,51-53). In the present study, the GPR30 immunoblotting assays showed that in the most differentiated mammary gland cell line (MCF-10A) there is a greater expression of GPR30 compared with expression levels in the cellular models of breast cancer that have a partially (MCF-7) or completely (MDA-MB-231) lost cell polarity. In turn, the difference observed between the GPR30 expression in MCF-7 and MDA-MB-231, helps to explain why the GPR30-dependent induction on proliferation deduced from viability assays with G15 in MCF-7 cells is more evident than in MDA-MB-231 cells. It is important to mention that the effect caused by G1 
A
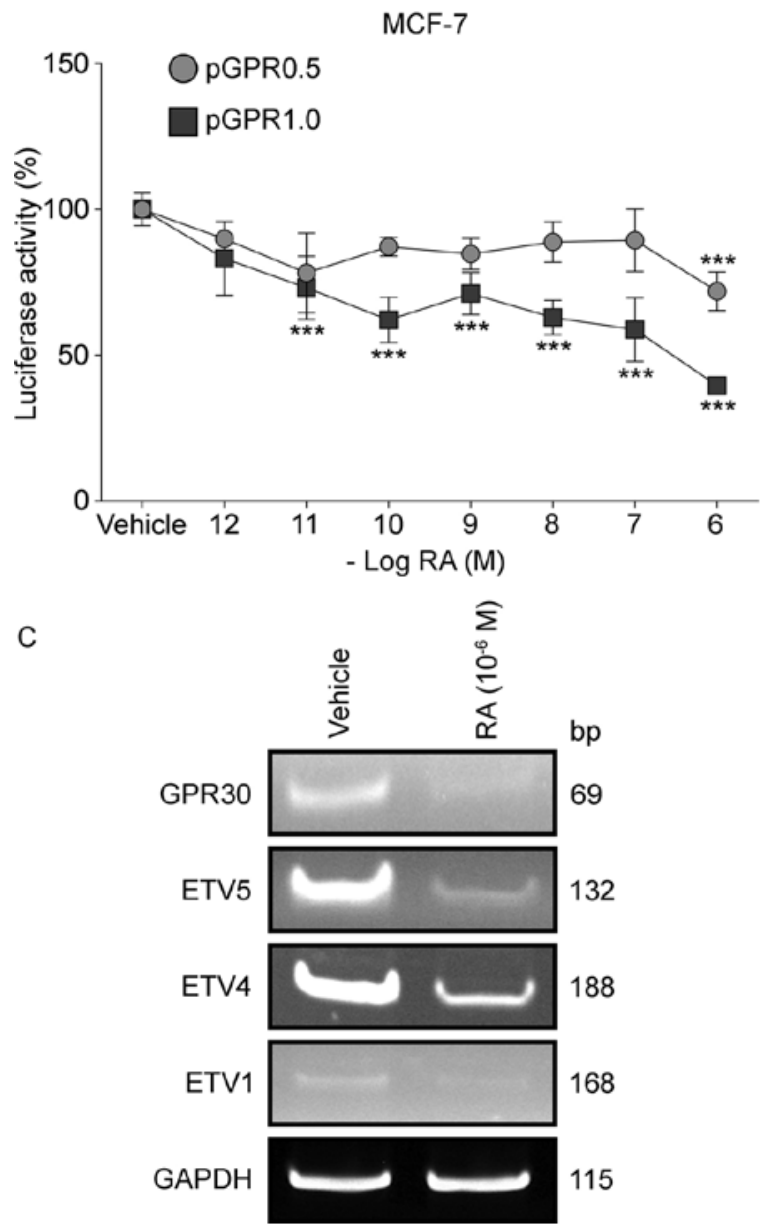

B

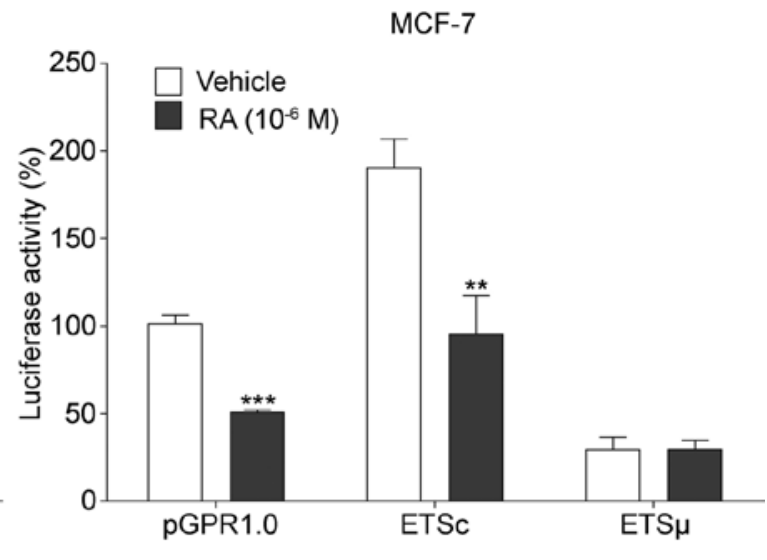

D

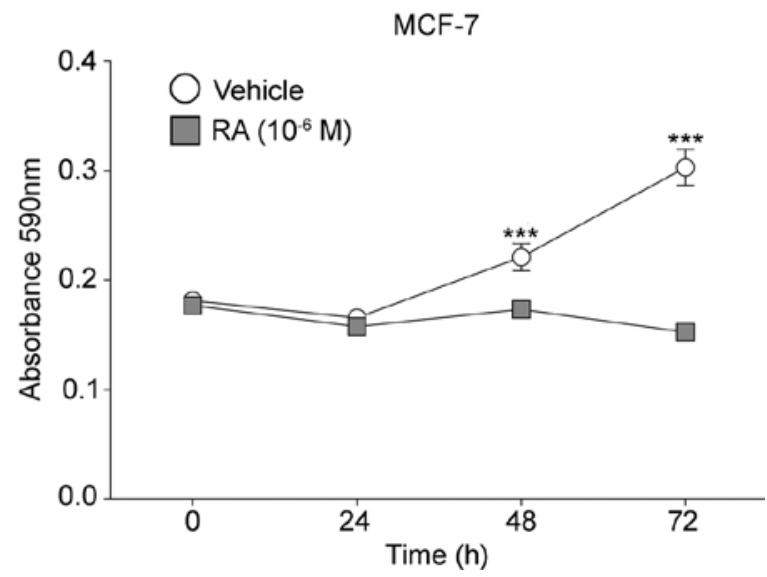

Figure 6. GPR30 promoter and the ETS cis-element located -630 bp from TSC is suppressed by RA in MCF-7 differentiated breast cancer cells. (A) Analysis of reporter gene activity of pGPR0.5 and pGPR1.0 in transient expression assays performed in MCF-7 cells exposed to a RA dose-response curve. ${ }^{* *} \mathrm{P}<0.01$, ${ }^{* * * *} \mathrm{P}<0.001$ vs. Vehicle. (B) Assessment of reporter gene activity of the pGPR1.0, ETSc and ETS $\mu$ constructs in RA-treated and untreated MCF-7 cells. ${ }^{* *} \mathrm{P}<0.01$, ${ }^{* * *} \mathrm{P}<0.001$ vs. Vehicle. (C) Effects of RA treatment $\left(10^{-6} \mathrm{M}\right)$ on mRNA expression of GPR30 and PEA3 subfamily factors in MCF-7 cells were determined by reverse transcription-PCR. (D) Viability of MCF-7 cells in the absence (vehicle control) and presence of RA. ${ }^{* *} \mathrm{P}<0.01,{ }^{* * *} \mathrm{P}<0.001 \mathrm{vs} .0 \mathrm{~h}$. Data are presented as the mean \pm SD of three independent experiments in triplicate. ETS, E26 transformation-specific; GPR30, G protein-coupled receptor 30; PEA3, polyomavirus enhancer activator 3 homolog; RA, retinoic acid; TSC, translation start codon.

on the viability of the two models of breast cancer was not considered for the interpretation of the GPR30 activity, since it has been recently reported that this agonist suppresses proliferation through an GPR30-independent pathway (54). Overall, these results, together with the gradual loss observed in transcriptional regulation of the GPR30 promoter in breast cancer cell lines, indicate that mammary gland epithelial cells such as MCF-10A have GPR30 activity and that this can be extinguished in the course of breast cancer as a result of gene expression reprogramming that the malignant cells undergo during their dedifferentiation. In this regard, several research groups have reported that this can occur with GPR30 in breast cancer through epigenetic mechanisms that act at the promoter level $(49,51,55)$.

However, the viability and migration assays of the present study show that despite the role epigenetic silencing may be playing in the expression of GPR30, poorly differentiated breast cancer cells, such as MDA-MB-231, still retain responsiveness to both the agonist and the GPR30 antagonist. Contrasting the results obtained from the viability assays with those of migration, it is interesting to note that agonist and antagonist of GPR30 promote contrary effect in the migration, which indicated that G1 may reduce migratory ability through GPR30 and that G15 may be able to at least partially block this suppressive effect. These results also suggested that GPR30 induced proliferation through a different pathway to the one with which it suppresses migration, which could help to explain how the antagonism proposed by some authors between proliferation and metastasis could happen (56). It was not possible to evaluate the effects of G1 and G15 on the migration of MCF-7 because this cell line showed no ability to migrate from untreated cells, which had been previously reported by other authors (57). It was also verified that the doses used in the different assays of viability and migration did not have toxic effects that would alter the results obtained (data not shown). Therefore, since the results indicated that GPR30 expression and function are subject to changes in cell differentiation in the course of breast cancer, it is possible to better interpret why there are some studies that report the expression of GPR30 as a risk factor for the use of hormonal 
therapy $(13,58)$ and other studies that postulate this receptor as a favorable prognostic factor for disease-free survival of patients with ER-positive breast cancer $(50,51,59)$.

Confirmation of GPR30 biological activity at different differentiation stages in breast cancer led to the investigation of the mechanisms that regulate GPR30 expression at the transcriptional level. The present study aimed to determine if there are different transcriptional mechanisms of GPR30 that match with its performance in the different phenotypes studied, since the studies in this regard are scarce and the majority have focused on establishing the role of epigenetic regulation in GPR30 expression $(16,51,55,60,61)$. The predictive analysis of cis-regulatory elements performed on the 5' flanking region of the GPR30 gene obtained of the two malignant cell lines found only three putative sites in DR1 (GC 70\%) and none in DR2 (AT 72\%) probably due to its low heterogeneity, whereas in the proximal region of greatest heterogeneity 11 putative sites were identified for diverse transcription factors previously related to breast cancer. According to the data obtained from the transient expression assays carried out with pGPR0.2, the basal activity in MDA-MB-231 cells resulted in six-fold lower than MCF-7 and eleven-fold lower than MCF-10A. These results support the notion that GPR30 could be downregulated by EMT epigenetic reprogramming that malignant cells may undergo $(51,55,61)$. However, this same epigenetic reprogramming could at the same time be indirectly involved in the positive regulation of GPR30 expression, since a specific cis-regulatory element for members of the ETS family found between -631 and -625 bp of the TSC in the promoter of GPR30 exhibited the greatest activity in MCF-7 and MDA-MB-231 breast cancer cells compared with activity in non-malignant mammary gland cells (MCF-10A), suggesting an incorporation of transcriptional regulators that were absent in the program of gene expression.

To determine possible transcription factors of the ETS family that may be involved in the transactivation of GPR30 through cis-regulatory element located between -631 and $-625 \mathrm{bp}$ from TSC, those repressor factors of this family, such as Ets-2 repressor factor, ETV6, ETV7, ETS-like gene 3, and E74-like factor 1, were identified through previous reports on their predominant function $(62,63)$. Subsequently, taking as inclusion criterion their relationship with the progression of breast cancer, only the activators ETS1 (64), ETS2 (65) and the PEA3 subfamily (66) remained as possible interactors with the ETS binding site of the GPR30 promoter. To complete this analysis, transient expression assays were conducted with the reporter constructs pGPR1.0 and pGPR0.5 in untreated MDA-MB-231 cells and in cells treated with inhibitors of the main phosphorylation pathways, including SB203580 (p38), H89 (PKA), PD98059 (ERK1/2); exposure to H89 and PD98059 produced the expected suppressor effect on the pGPR1.0 construct. Several previous studies have reported that the PKA and ERK phosphorylation pathways are overactivated during the development of breast cancer, which promotes the expression, stability and activation of several oncogenes (67-70). However, ETS1 and ETS2 are factors that only need to be phosphorylated by the ERK pathway to be activated $(71,72)$, whereas PEA3 subfamily factors can be phosphorylated by both PKA and ERK $(73,74)$. Western blotting data from the present study demonstrated that only ETV5 is expressed in the three mammary gland cell lines, where the activity of the ETS binding site was observed. Although these results suggested that ETV5 has the highest possibility of interacting with the GPR30 promoter in MCF-10A and MDA-MB-231, it does not imply that other factors, such as ETV1 in MCF-7, are not involved in the transactivation of GPR30.

Since cell growth is a process favored by the gene expression program of malignant cells with a still epithelial phenotype (56), as well as by GPR30 activation, it was proposed to investigate whether RA, an anti-proliferative agent frequently used as an adjuvant in the treatment of non-invasive breast cancer, exerted a suppressive effect on GPR30 expression. Transient expression assays in MCF-7 revealed that even though the GPR30 promoter does not harbor an RA response elements, this metabolite significantly decreased the activity not only of the promoter but also of ETS binding site found between -631 and $-625 \mathrm{bp}$ from TSC. The data of the RA-dependent reduction in the expression of GPR30 and the transcription factors possibly involved with its transcriptional regulation indicated that RA suppressed the activity of the transcription factors that bind to the cis-regulatory element in MCF-7 cells. The discrepancy between the results obtained from immunoblot and those from RT-PCR for the ETV4 expression may be due to a poor performance in the translation of their mRNA, since with the nuclear extracts of positive control (K562) was detected a $66 \mathrm{kDa}$ protein corresponding with the molecular weight of ETV4 (40).

In conclusion, the results suggested a possible mechanism by which GPR30-dependent cell viability in non-invasive and ER-positive breast cancer cells may be downregulated by RA, but with a risk of triggering dedifferentiation. This indicated that specific activation of GPR30 may contribute to the treatment of non-invasive breast cancer tumors, preventing the transition to a more aggressive phenotype or may intervene by reversing the invasiveness of more aggressive tumors for the use of a more conventional treatment. Given the implications that the mechanism proposed in the present study may have for the prognosis and optimization of treatments for breast cancer at specific stages, it is also important to consider that the evidence reported here comes only from in vitro assays. Therefore, it is required that in subsequent studies, the functional ETS site between -631 and -625 bp from the TSC in the GPR30 promoter, as well as its possible transfactors, be included in assays that have a closer approach to the in vivo conditions, such as RNA interference or CRISPR.

\section{Acknowledgements}

The authors wish to thank Ms. Isis Santos Paniagua [Medical Research Unit in Reproductive Medicine, Instituto Mexicano del Seguro Social (IMSS)] for the total mouse brain and nuclear OVCAR3 extracts, as well as for her guidance in the standardization of cell viability assays with crystal violet. We would also like to thank Dr Guadalupe Maya Nuñez (Medical Research Unit in Reproductive Medicine, IMSS) for the technical advice provided during the reverse transcription-PCR assays, and Dr Arturo Aguilar Rojas (Medical Research Unit in Reproductive Medicine, IMSS) for the MDA-MB-231 cell line (American Type Culture Collection) and for his technical advice during the standardization of wound-healing assays. 


\section{Funding}

The present study was supported by Fondo de Investigación en Salud IMSS (grant. nos. FIS/IMSS/PROT/G12/1154, FIS/IMSS/PROT/G12/1150 and FIS/IMSS/PROT/G17-2/1720) and IMSS and CONACYT scholarships from the Universidad Autónoma Metropolitana-Iztapalapa to DSB.

\section{Availability of data and materials}

The datasets used during the present study are available from the corresponding author upon request.

\section{Authors' contributions}

DSB, MAPS and AO conceived and designed the experiments. DSB, MAPS and PCG performed the experiments. DSB, MAPS and AO analyzed the data. MAPS, ZS and EB substantial contributed to the conception and drafting of work and revising it critically for important intellectual content. DSB, MAPS, PCG and AO wrote the paper. All authors read and approved the manuscript and agreed to be accountable for all aspects of the research in ensuring that the accuracy or integrity of any part of the work are appropriately investigated and resolved.

\section{Ethics approval and consent to participate}

Not applicable.

\section{Patient consent for publication}

Not applicable.

\section{Competing interests}

The authors declare that they have no competing interests.

\section{References}

1. Vergote I, Amant F, Leunen K, Van Gorp T, Berteloot P and Neven P: Metastatic breast cancer: Sequencing hormonal therapy and positioning of fulvestrant. Int J Gynecol Cancer 16 (Suppl 2): S524-S526, 2006.

2. DeSantis CE, Ma J, Gaudet MM, Newman LA, Miller KD, Goding Sauer A, Jemal A and Siegel RL: Breast cancer statistics, 2019. CA Cancer J Clin 69: 438-451, 2019.

3. Fan W, Chang J and Fu P: Endocrine therapy resistance in breast cancer: Current status, possible mechanisms and overcoming strategies. Future Med Chem 7: 1511-1519, 2015.

4. Barton M, Filardo EJ, Lolait SJ, Thomas P, Maggiolini M and Prossnitz ER: Twenty years of the G protein-coupled estrogen receptor GPER: Historical and personal perspectives. J Steroid Biochem Mol Biol 176: 4-15, 2018.

5. Ruan SQ, Wang SW, Wang ZH and Zhang SZ: Regulation of HRG- $\beta 1$-induced proliferation, migration and invasion of MCF-7 cells by upregulation of GPR30 expression. Mol Med Rep 6: $131-138,2012$.

6. Girgert R, Emons G and Gründker C: $17 \beta$-estradiol-induced growth of triple-negative breast cancer cells is prevented by the reduction of GPER expression after treatment with gefitinib. Oncol Rep 37: 1212-1218, 2017.

7. Molina L, Figueroa CD, Bhoola KD and Ehrenfeld P: GPER-1/GPR30 a novel estrogen receptor sited in the cell membrane: Therapeutic coupling to breast cancer. Expert Opin Ther Targets 21: 755-766, 2017.
8. Thomas P and Dong J: Binding and activation of the seven-transmembrane estrogen receptor GPR30 by environmental estrogens: A potential novel mechanism of endocrine disruption. J Steroid Biochem Mol Biol 102: 175-179, 2006.

9. Long N, Long B, Mana A, Le D, Nguyen L, Chokr S and Sinchak K: Tamoxifen and ICI 182,780 activate hypothalamic $\mathrm{G}$ protein-coupled estrogen receptor 1 to rapidly facilitate lordosis in female rats. Horm Behav 89: 98-103, 2017.

10. Bologa CG, Revankar CM, Young SM, Edwards BS, Arterburn JB, Kiselyov AS, Parker MA, Tkachenko SE, Savchuck NP, Sklar LA, et al: Virtual and biomolecular screening converge on a selective agonist for GPR30. Nat Chem Biol 2: 207-212, 2006.

11. Dennis MK, Burai R, Ramesh C, Petrie WK, Alcon SN, Nayak TK, Bologa CG, Leitao A, Brailoiu E, Deliu E, et al: In vivo effects of a GPR30 antagonist. Nat Chem Biol 5: 421, 2009.

12. Dennis MK, Field AS, Burai R, Ramesh C, Petrie WK, Bologa CG, Oprea TI, Yamaguchi Y, Hayashi S, Sklar LA, et al: Identification of a GPER/GPR30 antagonist with improved estrogen receptor counterselectivity. J Steroid Biochem Mol Biol 127: 358-366, 2011.

13. Mo Z, Liu M, Yang F, Luo H, Li Z, Tu G and Yang G: GPR30 as an initiator of tamoxifen resistance in hormone-dependent breast cancer. Breast Cancer Res 15: R114, 2013.

14. Pandey DP, Lappano R, Albanito L, Madeo A, Maggiolini M and Picard D: Estrogenic GPR30 signalling induces proliferation and migration of breast cancer cells through CTGF. EMBO J 28: 523-532, 2009.

15. Lucki NC and Sewer MB: Genistein stimulates MCF-7 breast cancer cell growth by inducing acid ceramidase (ASAH1) gene expression. J Biol Chem 86: 19399-19409, 2011.

16. Recchia AG, De Francesco EM, Vivacqua A, Sisci D, Panno ML, Andò S and Maggiolini M: The G protein-coupled receptor 30 is up-regulated by hypoxia-inducible factor-1alpha (HIF-1alpha) in breast cancer cells and cardiomyocytes. J Biol Chem 286: 10773-10782, 2011.

17. De Francesco EM, Maggiolini M and Musti AM: Crosstalk between Notch, HIF-1 $\alpha$ and GPER in Breast Cancer EMT. Int J Mol Sci 19: pii: E2011, 2018.

18. Ariazi EA, Brailoiu E, Yerrum S, Shupp HA, Slifker MJ, Cunliffe HE, Black MA, Donato AL, Arterburn JB, Oprea TI, et al: The G protein-coupled receptor GPR30 inhibits proliferation of estrogen receptor-positive breast cancer cells. Cancer Res 70: 1184-1194, 2010.

19. Chen ZJ, Wei W, Jiang GM, Liu H, Wei WD, Yang X, Wu YM, Liu H, Wong CK, Du J and Wang HS: Activation of GPER suppresses epithelial mesenchymal transition of triple negative breast cancer cells via NF-kB signals. Mol Oncol 10: 775-788, 2016.

20. Filardo EJ, Quinn JA, Frackelton AR Jr and Bland KI: Estrogen action via the G protein-coupled receptor, GPR30: Stimulation of adenylyl cyclase and CAMP-mediated attenuation of the epidermal growth factor receptor-to-MAPK signaling axis. Mol Endocrinol 16: 70-84, 2002.

21. Filigheddu N, Sampietro S, Chianale F, Porporato PE, Gaggianesi M, Gregnanin I, Rainero E, Ferrara M, Perego B, Riboni F, et al: Diacylglycerol kinase $\alpha$ mediates $17-\beta$-estradiol-induced proliferation, motility, and anchorage-independent growth of Hec-1A endometrial cancer cell line through the $\mathrm{G}$ protein-coupled estrogen receptor GPR30. Cell Signal 23: 1988-1996, 2011.

22. Ge C, Yu M and Zhang C: G protein-coupled receptor 30 mediates estrogen-induced proliferation of primordial germ cells via EGFR/Akt/ $\beta$-catenin signaling pathway. Endocrinology 153: 3504-3516, 2012

23. Hsu LH, Chu NM, Lin YF and Kao SH: G-protein coupled estrogen receptor in breast cancer. Int J Mol Sci 20: pii: E306, 2019.

24. Poola I, Abraham J, Liu A, Marshalleck JJ and DeWitty RL: The cell surface estrogen receptor, $\mathrm{G}$ protein-coupled receptor 30 (GPR30), is markedly down regulated during breast tumorigenesis. Breast Cancer (Auckl) 1: 65-78, 2008.

25. Wei W, Chen ZJ, Zhang KS, Yang XL, Wu YM, Chen XH, Huang HB, Liu HL, Cai SH, Du J and Wang HS: The activation of $G$ protein-coupled receptor 30 (GPR30) inhibits proliferation of estrogen receptor-negative breast cancer cells in vitro and in vivo. Cell Death Dis 5: e1428, 2014. 
26. Yu T, Liu M, Luo $\mathrm{H}$, Wu C, Tang $X$, Tang S, Hu $\mathrm{P}$, Yan $\mathrm{Y}$, Wang $\mathrm{Z}$ and Tu G: GPER mediates enhanced cell viability and motility via non-genomic signaling induced by $17 \beta$-estradiol in triple-negative breast cancer cells. J Steroid Biochem Mol Biol 143: 392-403, 2014.

27. Schreiber E, Matthias P, Müller MM and Schaffner W: Rapid detection of octamer binding proteins with 'mini-extracts', prepared from a small number of cells. Nucleic Acids Res 17: 6419,1989

28. Sambrook J, Fritsch EF and Maniatis T: Molecular cloning: A laboratory manual. Cold Spring Harbor Laboratory Press 1-3, 1989.

29. Filardo EJ and Thomas P: Minireview: G protein-coupled estrogen receptor-1, GPER-1: Its mechanism of action and role in female reproductive cancer, renal and vascular physiology. Endocrinology 153: 2953-2962, 2012.

30. Janknecht R, Monté D, Baert JL and de Launoit Y: The ETS-related transcription factor ERM is a nuclear target of signaling cascades involving MAPK and PKA. Oncogene 13: 1745-1754, 1996.

31. Wu J and Janknecht R: Regulation of the ETS transcription factor ER81 by the 90-kDa ribosomal S6 kinase 1 and protein kinase A. J Biol Chem 277: 42669-42679, 2002.

32. Yang JW, Kim MR, Kim HG, Kim SK, Jeong HG and Kang KW: Differential regulation of ErbB2 expression by cAMP-dependent protein kinase in tamoxifen-resistant breast cancer cells. Arch Pharm Res 31: 350-356, 2008.

33. Barrett JM, Puglia MA, Singh G and Tozer RG: Expression of Ets-related transcription factors and matrix metalloproteinase genes in human breast cancer cells. Breast Cancer Res Treat 72 227-232, 2002

34. Chotteau-Lelièvre A, Révillion F, Lhotellier V, Hornez L, Desbiens X, Cabaret V, de Launoit Y and Peyrat JP: Prognostic value of ERM gene expression in human primary breast cancers. Clin Cancer Res 10: 7297-7303, 2004.

35. Goueli BS and Janknecht R: Upregulation of the catalytic telomerase subunit by the transcription factor ER81 and oncogenic HER2/Neu, Ras, or Raf. Mol Cell Biol 24: 25-35, 2004.

36. Jiang J, Wei Y, Liu D, Zhou J, Shen J, Chen X, Zhang S, Kong X and $\mathrm{Gu}$ J: E1AF promotes breast cancer cell cycle progression via upregulation of Cyclin D3 transcription. Biochem Biophys Res Commun 358: 53-58, 2007.

37. Shepherd TG, Kockeritz L, Szrajber MR, Muller WJ and Hassell JA: The pea3 subfamily ETS genes are required for HER2/Neu-mediated mammary oncogenesis. Curr Biol 11: 1739-1748, 2001

38. Wu X and Sukumar S: ETS genes in breast cancer: A step in the right direction. Cancer Biol Ther 6: 83-84, 2007.

39. Hong H, Yu H, Yuan J, Guo C, Cao H, Li W and Xiao C: MicroRNA-200b impacts breast cancer cell migration and invasion by regulating Ezrin-Radixin-Moesin. Med Sci Monit 22: 1946-1952, 2016

40. Baert JL, Monté D, Musgrove EA, Albagli O, Sutherland RL and Launoit Y: Expression of the PEA3 group of ETS-related transcription factors in human breast-cancer cells. Int J Cancer 70 : 590-597, 1997.

41. Müller P, Kietz S, Gustafsson JA and Ström A: The anti-estrogenic effect of all-trans-retinoic acid on the breast cancer cell line MCF-7 is dependent on HES-1 expression. J Biol Chem 277: 28376-28379, 2002

42. Müller P, Crofts JD, Newman BS, Bridgewater LC, Lin CY, Gustafsson JA and Ström A: SOX9 mediates the retinoic acid-induced HES-1 gene expression in human breast cancer cells. Breast Cancer Res Treat 120: 317-326, 2010

43. Park S-W, Do H-J, Ha WT, Han MH, Song H, Uhm SJ, Chung HJ and Kim JH: Differential expression of ETS family transcription factors in NCCIT human embryonic carcinoma cells upon retinoic acid-induced differentiation. Biol Pharm Bull 37: 659-665, 2014.

44. Owman C, Blay P, Nilsson C and Lolait SJ: Cloning of human cDNA encoding a novel heptahelix receptor expressed in Burkitt's lymphoma and widely distributed in brain and peripheral tissues. Biochem Biophys Res Commun 228: 285-292, 1996.

45. Olde B and Leeb-Lundberg LM: GPR30/GPER1: Searching for a role in estrogen physiology. Trends Endocrinol Metab 20 : 409-416, 2009

46. Zhou X, Wang S, Wang Z, Feng X, Liu P, Lv XB, Li F, Yu FX, Sun Y, Yuan H, et al: Estrogen regulates Hippo signaling via GPER in breast cancer. J Clin Invest 125: 2123-2135, 2015
47. Scaling AL, Prossnitz ER and Hathaway HJ: GPER mediates estrogen-induced signaling and proliferation in human breast epithelial cells and normal and malignant breast. Horm Cancer 5: 146-160, 2014

48. Lappano R, Pisano A and Maggiolini M: GPER function in breast cancer: An overview. Front Endocrinol (Lausanne) 5: 66, 2014.

49. Weißenborn C, Ignatov T, Poehlmann A, Wege AK, Costa SD, Zenclussen AC and Ignatov A: GPER functions as a tumor suppressor in MCF-7 and SK-BR-3 breast cancer cells. J Cancer Res Clin Oncol 140: 663-671, 2014.

50. Martin SG, Lebot MN, Sukkarn B, Ball G, Green AR, Rakha EA Ellis IO and Storr SJ: Low expression of G protein-coupled oestrogen receptor 1 (GPER) is associated with adverse survival of breast cancer patients. Oncotarget 9: 25946-25956, 2018.

51. Manjegowda MC, Gupta PS and Limaye AM: Hyper-methylation of the upstream $\mathrm{CpG}$ island shore is a likely mechanism of GPER1 silencing in breast cancer cells. Gene 614: 65-73, 2017.

52. Ignatov T, Weißenborn C, Poehlmann A, Lemke A, Semczuk A, Roessner A, Costa SD, Kalinski T and Ignatov A: GPER-1 expression decreases during breast cancer tumorigenesis. Cancer Invest 31: 309-315, 2013.

53. Steiman J, Peralta EA, Louis S and Kamel O: Biology of the estrogen receptor, GPR30, in triple negative breast cancer. Am J Surg 206: 698-703, 2013.

54. Lv X, He C, Huang C, Hua G, Wang Z, Remmenga SW, Rodabough KJ, Karpf AR, Dong J, Davis JS and Wang C: G-1 inhibits breast cancer cell growth via targeting colchicine-binding site of tubulin to interfere with microtubule assembly. Mol Cancer Ther 16: 1080-1091, 2017

55. Weissenborn $\mathrm{C}$, Ignatov $\mathrm{T}$, Nass $\mathrm{N}$, Kalinski T, Dan Costa $\mathrm{S}$, Zenclussen AC and Ignatov A: GPER promoter methylation controls GPER expression in breast cancer patients. Cancer Invest 35: 100-107, 2017.

56. Kohrman AQ and Matus DQ: Divide or conquer: Cell cycle regulation of invasive behavior. Trends Cell Biol 27: 12-25, 2017.

57. Kamath L, Meydani A, Foss F and Kuliopulos A: Signaling from protease-activated receptor-1 inhibits migration and invasion of breast cancer cells. Cancer Res 61: 5933-5940, 2001.

58. Ignatov A, Ignatov T, Roessner A, Costa SD and Kalinski T: Role of GPR30 in the mechanisms of tamoxifen resistance in breast cancer MCF-7 cells. Breast Cancer Res Treat 123: 87-96, 2010.

59. Broselid S, Cheng B, Sjöström M, Lövgren K, Klug-De Santiago HL, Belting M, Jirström K, Malmström P, Olde B, Bendahl PO, et al: $\mathrm{G}$ protein-coupled estrogen receptor is apoptotic and correlates with increased distant disease-free survival of estrogen receptor-positive breast cancer patients. Clin Cancer Res 19: 1681-1692, 2013.

60. Vivacqua A, Lappano R, De Marco P, Sisci D, Aquila S, De Amicis F, Fuqua SA, Andò $S$ and Maggiolini M: G proteincoupled receptor 30 expression is up-regulated by EGF and TGF alpha in estrogen receptor alpha-positive cancer cells. Mol Endocrinol 23: 1815-1826, 2009.

61. Manjegowda MC and Limaye AM: DNA methylation dependent suppression of GPER1 in colorectal cancer. Med Res Arch 6, 2018.

62. Lelièvre E, Lionneton F, Soncin F and Vandenbunder B: The Ets family contains transcriptional activators and repressors involved in angiogenesis. Int J Biochem Cell Biol 33: 391-407, 2001.

63. Mavrothalassitis G and Ghysdael J: Proteins of the ETS family with transcriptional repressor activity. Oncogene 19: 6524-6532, 2000.

64. Kim GC, Kwon HK, Lee CG, Verma R, Rudra D, Kim T, Kang K, Nam JH, Kim Y and Im SH: Upregulation of Ets1 expression by NFATc2 and NFKB1/RELA promotes breast cancer cell invasiveness. Oncogenesis 7: 91, 2018.

65. Wallace JA, Li F, Balakrishnan S, Cantemir-Stone CZ, Pecot T, Martin C, Kladney RD, Sharma SM, Trimboli AJ, Fernandez SA, et al: Ets2 in tumor fibroblasts promotes angiogenesis in breast cancer. PLoS One 8: e71533, 2013.

66. de Launoit Y, Chotteau-Lelievre A, Beaudoin C, Coutte L, Netzer S, Brenner C, Huvent I and Baert JL: The PEA3 group of ETS-related transcription factors: Role in breast cancer metastasis. Adv Exp Med Biol 480: 107-116, 2000.

67. De Luca A, Maiello MR, D'Alessio A, Pergameno $M$ and Normanno N: The RAS/RAF/MEK/ERK and the PI3K/AKT signalling pathways: Role in cancer pathogenesis and implications for therapeutic approaches. Expert Opin Ther Targets 16 (Suppl 2): S17-S27, 2012.

68. Jiang P, Enomoto A and Takahashi M: Cell biology of the movement of breast cancer cells: Intracellular signalling and the actin cytoskeleton. Cancer Lett 284: 122-130, 2009. 
69. Nguyen DH, Hussaini IM and Gonias SL: Binding of urokinase-type plasminogen activator to its receptor in MCF-7 cells activates extracellular signal-regulated kinase 1 and 2 which is required for increased cellular motility. J Biol Chem 273: 8502-8507, 1998.

70. Palorini R, Votta G, Pirola Y, De Vitto H, De Palma S, Airoldi C, Vasso M, Ricciardiello F, Lombardi PP, Cirulli C, et al: Protein kinase A activation promotes cancer cell resistance to glucose starvation and anoikis. PLoS Genet 12: e1005931, 2016.

71. Svensson S, Jirström K, Rydén L, Roos G, Emdin S, Ostrowski MC and Landberg G: ERK phosphorylation is linked to VEGFR2 expression and Ets-2 phosphorylation in breast cancer and is associated with tamoxifen treatment resistance and small tumours with good prognosis. Oncogene 24: 4370-4379, 2005.
72. Switzer CH, Cheng RY, Ridnour LA, Glynn SA, Ambs S and Wink DA: Ets-1 is a transcriptional mediator of oncogenic nitric oxide signaling in estrogen receptor-negative breast cancer. Breast Cancer Res 14: R125, 2012.

73. Baert J-L, Beaudoin C, Coutte L and De Launoit Y: ERM transactivation is up-regulated by the repression of DNA binding after the PKA phosphorylation of a consensus site at the edge of the ETS domain. J Biol Chem 277: 1002-1012, 2002.

74. Keld R, Guo B, Downey P, Cummins R, Gulmann C, Ang YS and Sharrocks AD: PEA3/ETV4-related transcription factors coupled with active ERK signalling are associated with poor prognosis in gastric adenocarcinoma. Br J Cancer 105: 124-130, 2011. 